Trinity University

Digital Commons @ Trinity

Political Science Faculty Research

Political Science Department

2020

\title{
Trinity University's Summer Bridge Program: Navigating the Changing Demographics in Higher Education
}

John R. Hermann

Trinity University, jhermann@trinity.edu

Sheryl R. Tynes

Trinity University, stynes@trinity.edu

Wendy Apfel

Trinity University, wapfel@trinity.edu

Follow this and additional works at: https://digitalcommons.trinity.edu/polysci_faculty

Part of the Political Science Commons

\section{Repository Citation}

Hermann, J. R., Tynes, S., \& Apfel, W. (2020). Trinity University's summer bridge program: Navigating the changing demographics in higher education. Journal of Student Affairs Research and Practice, 57(5), 571-577. http://doi.org/10.1080/19496591.2020.1717964

This Article is brought to you for free and open access by the Political Science Department at Digital Commons @ Trinity. It has been accepted for inclusion in Political Science Faculty Research by an authorized administrator of Digital Commons @ Trinity. For more information, please contact jcostanz@trinity.edu. 
Hermann, J. R., Tynes, S., \& Apfel, W. (2020).

Trinity University's Summer Bridge Program: Navigating the Changing Demographics in Higher Education. Journal of Student Affairs Research and Practice ISSN: 1949-6591 (print)/1949-6605 (online)

\title{
Innovation in Practice Feature
}

Check for updates

\section{Trinity University's Summer Bridge Program: Navigating the Changing Demographics in Higher Education}

\author{
John R. Hermann, Trinity University \\ Sheryl Tynes, Trinity University \\ Wendy Apfel, Trinity University
}

\begin{abstract}
Recognizing the changing demographics of students applying to college coupled with Trinity University's responsibility to help our students succeed, we have created a Summer Bridge program that focuses on firstgeneration, underrepresented students (FGUS). Trinity's Summer Bridge program has been a success-both in terms of student performance and retention. The central purpose of our article is to explain how Trinity University's Summer Bridge program strategically and intentionally helps some of our most vulnerable students succeed during their first year of college.
\end{abstract}

Our article is divided into five sections. First, our study explores the demographic, economic, and cultural changes influencing higher education. We also explain the tangible and intangible benefits of a college education for first-generation, underrepresented students (FGUS). Second, we provide a brief discussion of the history of Trinity University and our Summer Bridge program. Third, our study describes our Summer Bridge program. Fourth, the data we collected examines how our Summer Bridge students' grades and retention rates compare to our other first-year students. And, fifth, our article concludes with a discussion of future directions for our Summer Bridge program and how it may apply to other higher educational institutions. In particular, we offer recommendations for other student affairs professionals who also will be experiencing an increase in first-generation, underrepresented students.

\section{The Times Are A-Changin'}

A sea change is underway in higher education. Demographic, economic, and cultural factors (McGee, 2015) are altering the landscape of students applying to college. For example, a marked decrease in the number of Caucasian students applying to college is in the works-a $17 \%$ decline from public and 26\% from private high schools in the next 15 years (Bransberger, 2017, p. 2). As WICHE "Data Insights" concluded, "The decreasing number of White high school graduates will be counterbalanced over the next decade by swift growth in the number of Hispanic

Correspondence concerning this article should be addressed to John Hermann, Political Science, Trinity University, One Trinity Place, San Antonio, TX 78212-7200. E-mail: jhermann@trinity.edu 
graduates, in particular, and Asian/Pacific Islanders" (Bransberger, 2017, p. 2). In the next decade, Hispanic high school students applying to college are projected to increase by almost 50\%. Similarly, in the next 15 years, there will be an expected increase of 30\% among Asian/ Pacific Islanders (Bransberger, 2017). Equally important, many of the students applying to college will be FGUS, including those who are PELL eligible.

The students on a college campus in the near future will look very different than those in the past (i.e., after the codification of GI Bill in 1944 and the Higher Education Act of 1965) and present. While the types of students applying to college will differ, there is one constant: "College is the bridge between potential and opportunity" (McGee, 2015, p. XII). McGee reaffirmed that a college education affords "greater job opportunities, more employment security, and higher immediate and lifetime earnings" (McGee, 2015, p. 85). Additionally, virtually all educators tout the intangible benefits of a college education, including living a fuller life, solving problems, communicating clearly (both orally and in writing), working in teams, and being more introspective. Other benefits of a college education include having "greater intellectual, artistic, and critical thinking skills, civic mindedness, martial stability, self-esteem, more successful children, greater ethnic and gender tolerance ... than their non-college counterparts" (Roth, 2013, p. 2).

Based on the tangible and intangible benefits of a college education, higher educational institutions have an awesome responsibility to educate students. They must also prepare students for academic success. The demographic changes among college-aged students will provide new challenges for universities. Still, like all universities, Trinity is responsible for creating an educational environment that leads to the possibility of success, especially during the critical first year. Hunter (2006) for example, explained the importance of successfully transitioning students from high school to college:

The first college year is not 'grade $13^{\prime}$... . Student success requires intentional efforts by those of us responsible for the academy. Higher education is not unlike many other large and complex organizational systems. Fortune 500 companies invest significant time and resources into management training for new employees ... Why should higher education be any different? We also need to effectively assimilate new members into our complex organization. Should we not also provide intentional programs to teach new students how to be effective students and not leave this important transition to serendipity? (pp. 4-5)

While students, in the end, must take ownership for their success, higher educational institutions must also properly prepare students for the rigors of college. Trinity has a long history of helping students reach their academic, career, and life goals.

\section{A Brief History of Trinity and Summer Bridge}

Trinity University is a small liberal arts college with a few select graduate programs located in the historic Monte Vista area in San Antonio, Texas. Trinity is currently celebrating its 150th anniversary and has a total enrollment of approximately 2,400 students. It advertises a 9-to-1 student/faculty ratio. It has Presbyterian roots, but since 1969 it has been an independent secular university. For over two decades, Trinity has been ranked first (except for 2018 when it came in second) in the western region among universities offering undergraduate and master's degrees.

The Summer Bridge Program began in 2010. It offered an Academic Success Program (ASP) for approximately a week before classes began. Students eligible for ASP were firstgeneration, PELL eligible, and football players. While ASP included football players, the First- 
Year Seminar was exclusively reserved for only first-generation and PELL eligible students under the old Common Curriculum and the new one introduced in 2015.

In 2015, Trinity created a new curriculum called Pathways. First-year students take a sixcredit hour foundational First-Year Experience course that meets five days a week during the first semester. Two days are devoted to a seminar and two are dedicated to the writing workshop in small sections of no more than 15 students. A common learning experience for all of the sections of each First-Year Experience takes up the fifth day. The First-Year Experience sets norms and expectations of what is required for college work. Students are introduced to great works of different disciplines; they are required to read at least 1,500 pages and write 40 pages in the course. Students also focus on developing their higher-order learning, speaking, research, and writing skills. Our First-Year Experience program has a dedicated First-Year Experience coordinator. Additionally, there is a two-day workshop for First-Year Experience faculty members at the conclusion of the Spring semester to review best practices and prepare for the following fall semester, which all faculty in Summer Bridge attend.

\section{Summer Bridge}

Summer Bridge begins with a short orientation on the first Sunday in August. The orientation introduces students to Summer Bridge's purpose, academic support resources, and culminates with a dinner for students, their families, faculty, and staff. Beginning a couple weeks before New Student Orientation (NSO), there is a three-day intensive Academic Success Program (ASP), which includes football players and students who select the FYE $A$ Successful Life. ASP includes several Welcome to The Academy Sessions, focusing on: transition to college, strength assessments, goal setting, time management, library resources, Pathways curriculum, how to communicate with professors, diversity and inclusion, campus resources, and community service opportunities. Two faculty members also offer classroom instruction that emphasizes critical thinking, writing skills, and college expectations.

ASP concludes with a special advising and registration session to help the students navigate the curriculum and to learn about the available academic support resources. Summer Bridge teaches the students to think strategically and intentionally. Equally important, Summer Bridge teaches the students help-seeking behavior. Problems will inevitably crop up. Students should know what to do and where to go based on the individual problem. For example, time management issues require academic coaches, whereas generalized anxiety issues necessitate counseling services.

At the conclusion of ASP, FGUS who enroll in Summer Bridge take a First-Year Experience entitled $A$ Successful Life. The content of the course is divided into three distinct sections: Definition of Success and Its Complexities, Barriers to Success, and Paths To Success. The students have four papers, journal entries, a midterm and final, and four oral presentations.

The class starts a week before the beginning of the semester and ends in late November. Summer Bridge students complete approximately $40 \%$ of their first semester prior to the Thanksgiving. Students can devote their time and energy to the other courses during the final stretch of the semester. Each class section of $A$ Successful Life has an appropriate balance of students who are first-generation only, PELL eligible only, and both first-generation and PELL eligible students.

A Successful Life faculty members meet weekly to discuss the class and their students during the semester it is offered. Meeting discussions range from the curriculum to preparing the 
students for graded assignments to (future) common learning experiences. The weekly meetings always begin with a discussion of any students in the class who are struggling. Strategies are offered in resolving student issues, such as students needing computers and familial and assimilation issues. The faculty in Summer Bridge also meet monthly during the spring and summer to discuss what worked in the class, including altering any of the assignments or readings. Faculty members write a common syllabus. In 2018, Summer Bridge had four sections of $A$ Successful Life. Each class section is co-taught with two faculty members, one covering the seminar and the other responsible for the writing workshop. All of the assignments in Summer Bridge are low stakes $-10 \%$ or less of the final grade.

While the course has always offered midterm grades, one section of $A$ Successful Life experimented with having individual meetings with students in 2018. The meetings focused on three issues: the strengths of the student, areas in need of improvement, and help-seeking strategies. The students were given a week to write a reflection e-mail to both faculty members about their impressions of the discussion. Most of the students valued the individual meetings. They found the conversation to be more meaningful and reflective than just a midterm report emailed to the students. Many of the faculty members also make themselves accessible during non-business hours. For example, some faculty members allow students to text or call them at virtually anytime. The dedicated faculty and proven strategies used have led to student success for our Summer Bridge students.

\section{The Success of Summer Bridge}

Table 1 displays the grade point averages of students enrolled in Summer Bridge in relation to FGUS not in Summer Bridge and all other first-year students (traditional students). As evidenced by Table 1, Summer Bridge students have higher overall grade point averages than FGUS that chose not to enroll in the program in six of the eight years where data is available. The extra attention and proven strategies used in Summer Bridge appear to pay dividends for students who decide to enroll in the program.

Table 1

First-Year Students' GPA's: Comparative Analysis of Summer Bridge with FGUS/PELL Non-Summer Bridge and Traditional Students

\begin{tabular}{lcccc}
\hline Year & $\begin{array}{c}\text { Summer } \\
\text { Bridge (n) }\end{array}$ & $\begin{array}{c}\text { FGUS/PELL Non-Summer } \\
\text { Bridge (n) }\end{array}$ & $\begin{array}{c}\text { Traditional } \\
\text { Students (n) }\end{array}$ & $\begin{array}{c}\text { All First- Year } \\
\text { Students (n) }\end{array}$ \\
\hline Fall 2010 & $3.20(15)$ & $3.06(140)$ & $3.11(432)$ & $3.10(582)$ \\
Fall 2011 & $3.13(10)$ & $3.04(157)$ & $3.12(469)$ & $3.11(636)$ \\
Fall 2012 & $2.78(23)$ & $2.92(144)$ & $3.03(428)$ & $3.00(595)$ \\
Fall 2013 & $3.03(23)$ & $2.92(99)$ & $3.09(412)$ & $3.05(534)$ \\
Fall 2014 & $2.96(31)$ & $2.95(114)$ & $3.09(509)$ & $3.06(654)$ \\
Fall 2015 & $3.04(30)$ & $3.04(109)$ & $3.07(463)$ & $3.07(602)$ \\
Fall 2016 & $3.07(40)$ & $2.99(119)$ & $3.11(503)$ & $3.08(662)$ \\
Fall 2017 & $3.21(47)$ & $3.17(98)$ & $3.21(497)$ & $3.21(642)$ \\
\hline
\end{tabular}


As Table 1 also shows, traditional Trinity students, those who are not first-generation or PELL eligible, had slightly higher grade point averages than Summer Bridge students in five of the eight years. The largest difference was in 2012, 2.78 for Summer Bridge and 3.03 for traditional Trinity students; this was the only year that the difference between the two groups was more than a tenth of a hundredth in terms of grade point average. In 2017, Summer Bridge and traditional Trinity students had an identical grade point average of 3.21. Finally, in two years (2010 and 2011), Summer Bridge students had higher grade point averages than traditional Trinity students. Overall, the academic success of FGUS enrolled in Summer Bridge was impressive. First-generation and PELL eligible students are presented with "a foreign set of norms, traditions, rituals, and a new environment" (Hunter, 2006, p. 4). Their assimilation process to college is less likely to be seamless in relation to students who had parents who went to college and went to richer public and private high schools (McGee, 2015). Yet, Summer Bridge students largely performed better than FGUS not enrolled in the program. The difference between traditional Trinity students and our Summer Bridge students' grade point averages were separated by the slightest of margins.

Perhaps more important are the retention rates of Summer Bridge students in comparison to their cohorts. If students drop out of college, their career, academic, and life goals are usually more limited than those with a four-year degree. What is more, college loans are secured loans and are not forgivable in bankruptcy court. Table 2 reveals that Summer Bridge students' retention rates were higher than FGUS not in summer Bridge and traditional Trinity students in six of the eight years where data were collected. In all of those six years, our Summer Bridge students had retention rates of $90 \%$ or higher. In only one year (2013), Summer Bridge students had retention rates lower than FGUS not enrolled in the program.

Given the small number of students who participate in Summer Bridge each year, we were not able to use inferential or associational statistics to demonstrate how our program relates to our control groups, FGUS who do not participate in Summer Bridge and traditional first-year students. Based on previous research, however, FGUS have lower grade points averages and retention rates than traditional students (Sablan, 2014; Suzuki, Amrein-Beardsley, \& Perry, 2012). FGUS are in a vulnerable position when attending college. They experience a new set of

Table 2

First-Year Students' Retention Rates (One-Year Lag): Comparative Analysis of Summer Bridge with FGUS/ PELL Non-Summer Bridge and Traditional Students

\begin{tabular}{lcccc}
\hline Year & $\begin{array}{c}\text { Summer Bridge } \\
\text { (n) }\end{array}$ & $\begin{array}{c}\text { FGUS/PELL Non-Summer } \\
\text { Bridge (n) }\end{array}$ & $\begin{array}{c}\text { Traditional } \\
\text { Students (n) }\end{array}$ & $\begin{array}{c}\text { All First-Year } \\
\text { Students (n) }\end{array}$ \\
\hline Fall 2010 & $100 \%(15)$ & $84 \%(140)$ & $90 \%(432)$ & $89 \%(582)$ \\
Fall 2011 & $100 \%(10)$ & $89 \%(157)$ & $89 \%(469)$ & $89 \%(636)$ \\
Fall 2012 & $91 \%(23)$ & $89 \%(144)$ & $88 \%(428)$ & $88 \%(595)$ \\
Fall 2013 & $74 \%(23)$ & $88 \%(99)$ & $89 \%(412)$ & $88 \%(534)$ \\
Fall 2014 & $94 \%(31)$ & $88 \%(114)$ & $90 \%(509)$ & $90 \%(654)$ \\
Fall 2015 & $90 \%(30)$ & $89 \%(109)$ & $89 \%(463)$ & $89 \%(602)$ \\
Fall 2016 & $88 \%(40)$ & $94 \%(119)$ & $88 \%(503)$ & $88 \%(662)$ \\
Fall 2017 & $96 \%(47)$ & $93 \%(98)$ & $90 \%(497)$ & $91 \%(642)$ \\
\hline
\end{tabular}


norms that are unfamiliar to them. While the literature suggests that struggling (e.g., Bjork \& Bjork, 2011) or even failing (e.g., Duckworth, 2016; Dweck, 2016) are key to a student's academic success, many FGUS do not have that luxury. It is important that universities provide the necessary resources for FGUS to succeed. In Trinity's case, Summer Bridge provides a program rooted in helping our most at-risk first-year students.

\section{Conclusion}

Based on our Summer Bridge program, there is little doubt that Trinity has taken an active step in helping FGUS succeed in college. Still, other strategies are needed to reinforce student success. In Trinity's case, the creation of the Student Success Center and the Quality Enhancement Plan entitled "Starting Strong" are two additional initiatives that help students' improve their academic performance and retention rates.

In the fall of 2015, Trinity University hired a full-time director for academic support in our Student Success Center, which has subsequently added a full-time academic coach. The director of academic support and the academic coach have individual meetings with students on how to improve student persistence. They also offer workshops on topics such as how to cope with test anxiety, note taking, time management, study strategies, and how to read critically. For students on academic probation, a one-credit Academic Success course is offered.

To further enhance the coordination of these efforts, Student Accessibility Services, the Writing Center, and Academic Support were brought together into one physical location on the main floor of our library. The new space is called the Tiger Learning Commons and led by the academic support director. The Tiger Learning Commons provides a centralized hub for academic coaching, tutoring, and student accessibility services.

Additionally, Trinity University's Quality Enhancement Plan, part of the Southern Association of Colleges and Schools Commission on Colleges' reaffirmation of accreditation criteria, entitled "Starting Strong: Intentional Strategies for Improving First-Year Student Success" focuses on improving first-year advising, teaching, and academic support resources. Trinity hired a full-time advising coordinator, who helps faculty and students with advising and registration. Faculty members are kept up to date on latest "best practices" in advising.

In connection with teaching, "Starting Strong" has faculty notify advisers, administrators, and academic support staff of issues with students with "early alert" notifications during the fifth week in the semester. Faculty members are also incentivized through small grants to use more low stakes assignments in their syllabi. Finally, academic support resources was improved by hiring a full-time quantitative reasoning and skills (QRS) director, who helps with student success in STEM courses. Given that $53 \%$ of our entering class expresses interest in a STEM-related field coupled with the fact that the vast majority of our gateway classes reside in STEM, the QRS director should be invaluable in helping with student persistence and retention. Finally, the QRS director will lead a Summer Bridge Math class prior to the start of the fall semester for students who need extra help in succeeding in STEM-related courses. The Summer Bridge Program's success is bolstered by both the creation of the Student Success Center and the Quality Enhancement Plan.

Additionally, Summer Bridge created a mentor program of upper-class students and peer tutors who participated in the program for FGUS. Faculty members are also playing an active role in mentoring. Faculty members in Summer Bridge work with Alumni Relations to secure external funding to keep up with the increasing demand of Summer Bridge. We are also exploring writing grants to secure more funding for Summer Bridge. Still, when a program 
grows, we need to be careful it does not lose the personal relationships forged between administration, faculty, staff, and students.

For student-life professionals who are responsible for the success of FGUS, we recommend that they focus on improving student engagement at their higher educational institutions. For example, Pope (2018) found that students who participate in experiential learning and are active in extracurricular activities are more likely to succeed in college than students who do not participate in these types of activities. Students must feel a sense of belonging and that they are a valued member of the community (Sablan, 2014, p. 1045; Suzuki et al., 2012). Finally, student-life professionals must lobby for funds for Summer Bridge programs to ensure that FGUS can successfully assimilate to college (Sablan, 2014).

As the demographics continue to change, FGUS will be more commonplace on college campuses across the country. Investing our time and resources to help our students succeed should always be our top priority. Darwinian natural selection for our students in higher education must be replaced with a more compassionate and caring approach during their critical first year of college. If a student is accepted to a university, we have an obligation to make sure that the student has the necessary skills to succeed. Otherwise, we are not fulfilling our promise to students of all the tangible and intangible benefits of a college education.

\section{References}

Bjork, E. L., \& Bjork, R. A. (2011). Making things hard on yourself, but in a good way: Creating desirable difficulties to enhance learning. In M. A. Gernsbacher, R. W. Pew, L. M. Hough, \& J. R. Pomerantz (Eds.), Psychology and the real world: Essays illustrating fundamental contributions to society (pp. 56-64). New York, NY: Worth Publishers.

Bransberger, P. (2017, July). Data insights: Fewer students, more diversity: The shifting demographics of high school graduates. Retrieved from www.wiche.edu.

Duckworth, A. (2016). Grit: The power of passion \& perseverance. New York, NY: Simon \& Schuster.

Dweck, C. (2016). Mindset: New psychology of success. New York, NY: Ballantine Books.

Hunter, M. S. (2006, Summer). Fostering student learning and success through first-year programs. Peer Review, 8(3), 4-8.

McGee, J. (2015). Breakpoint: The changing marketplace for higher education. Baltimore, MD: Johns Hopkins University Press.

Pope, D. (2018, October) A fit over rankings: Why college engagement matters more than selectivity. Retrieved from www. challengesuccess.org

Roth, A. (2013, June 6). Strength of character: The unique good of higher education. Retrieved from www.evollution.com/ strength-character-unique-good-higher.

Sablan, J. R. (2014). The challenge of summer bridge programs. American Behavioral Scientist, 58(8), $1035-1050$. doi: $10.1177 / 0002764213515234$

Suzuki, A., Amrein-Beardsley, A., \& Perry, N. (2012). A summer bridge program for underrepresented first-year students: Confidence, community, and re-enrollment. Journal of First-Year Experience \& Students in Transition, 24(2), 85-106. 